\title{
Implementation Policy of Cultural Diplomacy of West Papua Province and Defense Diplomation Relationship in the Ministry of Defense of the Republic of Indonesia
}

\author{
Dian Damayanti \\ Institut Ilmu sosial dan Manajemen STIAMI Dki Jakarta Indonesia
}

\begin{abstract}
The principle of Indonesian diplomacy is 'One Million Friends without Enemies' diplomacy. Agencies and organizations that carry out defense and development activities consistently avoid security issues (high politics) that are closely related to ideology and politics. Security focuses on defending the country against military threats that emanate from outside its territory. When the cold war ended, the concept of security was transformed. After the Cold War, there was a change in the balance of power and the opening of doors for international organizations other than the state to interact.
\end{abstract}

The view of security shifted so that it demanded the democratization of the security sector and allowed changes to the security institutions to follow the principles of democracy. Traditional interpretations in terms of interaction between nations are no longer talking about security (security) related to military power (high politics) but security is also influenced by economic, social and cultural, technological progress (low politics). This study uses a qualitative method. Based on the results of research and discussion regarding the implementation of cultural diplomacy of West Papua and defense diplomacy policies at the Ministry of Defense of the Republic Indonesia, the following conclusions can be drawn: Researchers in analyzing used the concept of Edward III (1980). Important functions for a country, among others, are the diplomatic functions of representation, where in this function, delegates from one country negotiate with other countries with a purpose that is to explain some of these countries. Then the diplomacy function in the negotiation function, in this function a country has the right to negotiate related to the country in terms of negotiations related to trade or bilateral cooperation of a country. And lastly there is a diplomacy function in the reporting function, where in this function a diplomat conducts negotiations about the culture, military, and commercial issues in his country.

Keywords: Cultural Diplomacy, Defense Diplomacy, Cold War, Democracy, Economic, Social, Cultural, Technological. 


\section{INTRODUCTION}

The principle of Indonesian diplomacy is 'One Million Friends without Enemies' diplomacy. Agencies and organizations that carry out defense and development activities consistently avoid security issues (high politics) that are closely related to ideology and politics. Security focuses on defending the country against military threats that emanate from outside its territory. When the cold war ended, the concept of security was transformed. After the Cold War, there was a change in the balance of power and the opening of doors for international organizations other than the state to interact. The view of security shifted so that it demanded the democratization of the security sector and allowed changes to the security institutions to follow the principles of democracy. Traditional interpretations in terms of interaction between nations are no longer talking about security (security) related to military power (high politics) but security is also influenced by economic, social and cultural, technological progress (low politics).

\section{THEORIES}

\section{A. Implementation Policy}

Attitude that will bring on themselves offender disposition policies. High disposition by Edward III (1980) and Van Horn and Van Meter (1975) effect on the rate of successful implementation of the policy [1]. Disposition for Edward III (1980:53) is defined as the tendency, desire or agreement of the executive to implement the policy. If you want to be successful policy implementation effectively and efficiently, the executor is not just knowing what to do and have the willingness to carry out that policy, but they also have to have the will to implement the policy. The role of the actors in policy implementation is proposed by Edwards III (1980: 12) who states that "Public policies are made and implemented on the national, state, and local levels. Often implemented by lower level by units of government. " This suggests that public policy is made and implemented at the national level, state, and local government. According to Edward III and George C. (1980: 12), there are four critical variables or factors that determine the success of policy implementation, namely communication, resources, disposition or attitude, and bureaucratic structure. Edward III (1980: 12) holds that policy implementation is influenced by four variables, namely: namely: communication, resources, dispositions or attitudes, and bureaucratic structure (bureaucratic structure) .

\section{B. Clutural Diplomation}

Diplomacy is categorized into two, namely first track diplomacy and multitrack diplomacy. According to Jeffrey Mependere in his writing "Track one and a half diplomacy and the contemporary of tracks", he explained that first track diplomacy involves government and government (government to geverment), is secret in nature, and is usually used to end a conflict or dispute. First track diplomacy emphasizes the important role of the state in holding negotiations to maintain and maintain peace [2]. Multi track diplomacy or better known as public diplomacy is an effort to achieve the national interests of a country through understanding, informing, and influencing foreign audiences [3]. If the traditional diplomacy process is developed through the goverment to government relations mechanism, then public diplomacy is more emphasized on government to people or people to people relations. Public diplomacy aims to find friends among the people of the country to be able to contribute in 
efforts to build good relations with other countries. According to Leonar, there are four objectives of public diplomacy in the 21 st century, namely: 1 . Increase familiarity-make people think and change their perception of the country, and increase people's knowledge about the country. 2. Increase appreciation-presenting a positive perception by making people see an issue from the perspective of the country. 3. Embracing society - encourages people to see a country as an attractive destination for tourism and study, buy goods, or adopt the country's values. 4. Influencing people's attitudes - increasing public support for the position of the country [4].

Cultural diplomacy is part of Public Diplomacy (Softpower Diplomacy) by relying on the strength of economic and cultural cooperation, as opposed to the word of hard power which is based on military power. In other words, soft power is the ability to get what is desired by inviting and attracting the sympathy of other countries so that other countries can equally realize the interests of a country (Mohammad Shoelhi, 2011, p. 84) [5].

Cultural diplomacy is a very interesting and important thing in the world of International Relations. Cultural diplomacy is not carried out in a government-to-government mechanism but emphasizes government-to-community relations and the most important thing is community-to-community relations. Cultural diplomacy is considered a tool to show the level of civilization of a nation. Someone who has paid attention to something or the culture of a certain country, will arise a deep curiosity about the country that has that interest [6]. Triyono believes that cultural, artistic and cultural diplomacy will make a positive contribution to creating world peace. Triyono sparked the motto of "a million friends and zero enemy" through the relationship between communities known as "people contact" and can be further intertwined [7].

\section{Defense Diplomacy}

Defense diplomacy is all means and strategies through various aspects of cooperation such as economics, culture, politics, defense and diplomacy so that countries can have friendly relations, can further cooperate with each other, and the most important thing is to increase trust. Defense diplomacy is used as a tool to achieve a country's foreign policy targets [8]. Gregory Winger in his article The Theory of Defense Diplomacy explains that defense diplomacy is a way of using the military not for violence, such as officer exchanges, warship visits, joint military exercises in order to achieve a country's international interests [9]. Still in Winger's writing, Andre Cottey and Anthony Foster stated that defense diplomacy is the use of the military in peacetime as a tool for security policy and foreign relations. This is reinforced by Martin Edmons who defines defense diplomacy as the use of the military for operations other than war by leveraging his training and disciplinary experience to achieve national interests both at home and abroad. The success of the implementation of defense diplomacy is highly dependent on diplomatic efforts at the global, regional and bilateral levels. Of all that, diplomacy at the bilateral level plays a very important role. The success of a country's defense diplomacy strategy is a collaboration of the diplomacy, defense and development components. However, partially there are the main characteristics of a country's defense diplomacy: 1) Defense diplomacy for Confidence Building Measures; 2) Defense Diplomacy for defense capabilities; 3) Defense Diplomacy for Defense industry [10]. 


\section{Research Model}

The legal basis relating to national defense and security regulated in the 1945 Constitution is as follows: Article 30 paragraph 1 and paragraph 2 of the 1945 Constitution Article 30 of the 1945 Constitution is an article regulating the defense and security of the Indonesian state and the legal constitution basis to national culture article 32 of the 1945. is an article regulating the culture

Policy implementation:
1. Communication
2. Resources
3. Dispositions
4. Bureaucratic Structure
Source: Edward III. 1980 p. 148.
important functions for a country, among others, are the diplomatic functions of representation, where in this
function, delegates from one country negotiate with other countries with a purpose that is to explain some of
these countries. Then the diplomacy function in the negotiation function, in this function a country has the right
to negotiate related to the country in terms of negotiations related to trade or bilateral cooperation of a country.
And lastly there is a diplomacy function in the reporting function, where in this function a diplomat conducts
negotiations about the culture, military, and commercial issues in his country.




\section{METHODOLOGY}

Qualitative research is a means for exploring and understanding the meaning individuals or groups ascribe to a social or human problem. The process of research involves emerging questions and procedures. Data typically collected in the participant's setting. data analysis inductively building from particulars to general themes. and the researcher making interpretations of the meaning of the data. The final written report has a flexible structure. Those who engage in this form of inquiry support a way of looking at research that honors an inductive style, a focus on individual meaning. and the importance of rendering the complexity of a situation[11].

\section{Informants}

1. Minister of Education and Culture of the Republic of Indonesia

2. Minister of Foreign Affairs

3. Ministry of defence

\section{RESEARCH RESULTS, AND RESEARCH DISCUSSION}

\section{Implementation Policy of Cultural Diplomation Of West Papua And Defense Diplomacy At The Ministry Of Defense Of The Republic Indonesia.}

Based on the results of research and discussion regarding the implementation of cultural diplomacy of West Papua and defense diplomacy policies at the Ministry of Defense of the Republic Indonesia, the following conclusions can be drawn: Researchers in analyzing used the concept of Edward III (1980). Important functions for a country, among others, are the diplomatic functions of representation, where in this function, delegates from one country negotiate with other countries with a purpose that is to explain some of these countries. Then the diplomacy function in the negotiation function, in this function a country has the right to negotiate related to the country in terms of negotiations related to trade or bilateral cooperation of a country. And lastly there is a diplomacy function in the reporting function, where in this function a diplomat conducts negotiations about the culture, military, and commercial issues in his country.

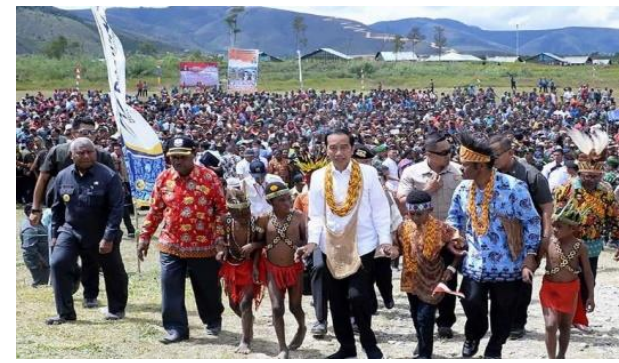

Figures 1

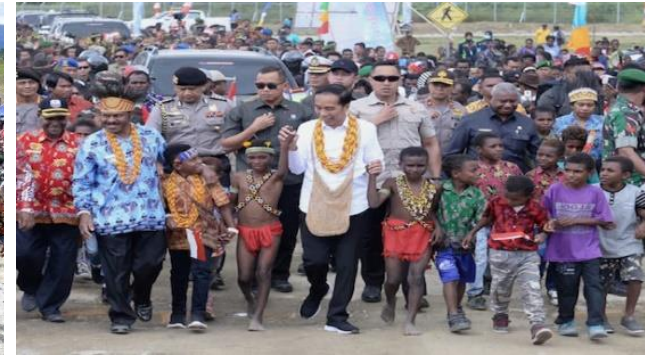

Figures 2

1. Has the ministry informed employees and conducted socialization on the Policy for the Implementation of West Papua Cultural Diplomacy and Defense Diplomacy at the Ministry of Defense of the Republic of Indonesia? explain the obstacles and efforts used in the implementation of West Papua Cultural Diplomacy and Defense Diplomacy! 
The Ministry has informed employees and disseminated the Policy for the Implementation of West Papua Cultural Diplomacy and Defense Diplomacy at the Ministry of Defense of the Republic of Indonesia with the result that the ministry employees know The principle of Indonesian diplomacy is 'One Million Friends without Enemies' diplomacy. Agencies and organizations that carry out defense and development activities consistently avoid security issues (high politics) that are closely related to ideology and politics. Security focuses on defending the country against military threats that emanate from outside its territory. When the cold war ended, the concept of security was transformed. After the Cold War, there was a change in the balance of power and the opening of doors for international organizations other than the state to interact. The view of security shifted so that it demanded the democratization of the security sector and allowed changes to the security institutions to follow the principles of democracy. Traditional interpretations in terms of interaction between nations are no longer talking about security (security) related to military power (high politics) but security is also influenced by economic, social and cultural, technological progress (low politics). constraints and efforts used in the implementation of West Papua Cultural Diplomacy and Defense Diplomacy that the problems of public diplomacy are not only a challenge to foreign policy, but also a national challenge. The essence of public diplomacy is to "get other people on your side", while the problem in public diplomacy is how to influence the opinions and behavior of others. In this case, what people mean is not only policy makers, but also audiences or the public. As a soft power instrument, the development of public diplomacy is quite rapid. The rapid development of this was triggered by the fact that the efforts made by the government in the first line of diplomacy are considered to have failed to overcome conflicts between countries. The failure of the first line of diplomacy has developed the idea of increasing public diplomacy as an alternative way of resolving conflicts between countries. The application of public diplomacy cannot be separated from the communication of foreign policy to the foreign public. The main characteristic of public diplomacy is that it involves all stakeholders in the process. Stakeholders here are not only the Department of Foreign Affairs, but also across departments within the government, private sector, NGOs, media, and individuals. With such a diverse and large portion of involvement, the design of a communication strategy must be put forward.

Communication Based on the results of research and discussion regarding the implementation of cultural diplomacy of West Papua and defense diplomacy policies at the Ministry of Defense of the Republic Indonesia, the following conclusions can be drawn: Researchers in analyzing used the concept of Edward III (1980). Important functions for a country, among others, are the diplomatic functions of representation, where in this function, delegates from one country negotiate with other countries with a purpose that is to explain some of these countries. Then the diplomacy function in the negotiation function, in this function a country has the right to negotiate related to the country in terms of negotiations related to trade or bilateral cooperation of a country. And lastly there is a diplomacy function in the reporting function, where in this function a diplomat conducts negotiations about the culture, military, and commercial issues in his country. 
2. Is there an increase in quality and quantity and continuous improvement of employee performance and socialization of excellent service culture? explain what obstacles are in resources?

At the ministry there has been an increase in quality and quantity as well as continuous improvement in employee performance, such as training and providing scholarships for employees. The socialization of excellent service culture in the ministry aims to provide an understanding of excellent service to the community and can be implemented in daily activities. Broadly speaking, the socialization material presented is as follows: Information \& complaints desk clerk must have product knowledge in order to provide excellent service. Reliable communication skills are also very important in understanding what the public wants, focus on community, provide efficient service, personal approach, foster good relations with the community. Show sympathy, speak with feelings, and provide solutions to show that you understand what society wants. Ask for community responses in the form of a service satisfaction survey so that it can be corrected if there are deficiencies in service. Limited personnel constraints such as IT and cyber forensic experts, another crucial obstacle is the limited operational budget funds, crucial issues besides legal instruments, namely the lack of human resources, budget and facilities and infrastructure to support the Policy for the Implementation of West Papua Cultural Diplomacy and Defense Diplomacy at the Ministry of Defense of the Republic of Indonesia. Currently the budget is only sufficient for one case per month. Weak supervision of the use of the internet has the potential to create opportunities for defense diplomacy problems. The procedural constraints on the IT Law and those from the Ministry of Communication and Information Technology (KOMINFO) are directly related to the policy on the use of information technology and internet facilities in Indonesia. It can be said that the ability of Indonesian polyclinics in cyberspace is still at the standard or beginner level. human resources Based on the results of research and discussion regarding the implementation of cultural diplomacy of West Papua and defense diplomacy policies at the Ministry of Defense of the Republic Indonesia, the following conclusions can be drawn: Researchers in analyzing used the concept of Edward III (1980). Important functions for a country, among others, are the diplomatic functions of representation, where in this function, delegates from one country negotiate with other countries with a purpose that is to explain some of these countries. Then the diplomacy function in the negotiation function, in this function a country has the right to negotiate related to the country in terms of negotiations related to trade or bilateral cooperation of a country. And lastly there is a diplomacy function in the reporting function, where in this function a diplomat conducts negotiations about the culture, military, and commercial issues in his country.

3. Has the Ministry office implemented reward and punishment for employees and made continuous improvements to employee performance in your opinion and what are the disposition constraints and efforts to implement the Policy for the Implementation of West Papua Cultural Diplomacy and Defense Diplomacy at the Ministry of Defense of the Republic of Indonesia?

In my opinion, the ministry has implemented reward and punishment for employees. Employees who receive awards for their services as well as promotions and salary increases. Meanwhile, employees who receive punishment usually receive a reprimand from discipline, for example, or at worst. 
Reliable communication skills are also very important in understanding what people want, focusing on the community, providing efficient service, personal approach, fostering good relations with the community. Show sympathy, speak with feelings, and provide solutions to show that you understand what society wants. Ask for community responses in the form of a service satisfaction survey so that it can be corrected if there are deficiencies in services. Limited personnel constraints such as IT and cyber forensics experts, another crucial obstacle is the limited operational budget funds, crucial problems besides legal instruments, namely the lack of human resources, budget and facilities and infrastructure to support the West Papua Cultural Implementation Policy. Diplomacy and Defense Diplomacy of the Ministry of Defense of the Republic of Indonesia. Currently the budget is only sufficient for one case per month. Weak surveillance of the use of the internet has the potential to create problems for defense diplomacy. Procedural constraints on the IT Law and from the Ministry of Communication and Information Technology (KOMINFO) are directly related to the policy on the use of information technology and internet facilities in Indonesia. It can be said that the ability of Indonesian polyclinics in cyberspace is still at the standard or beginner level. Disposition Based on the results of research and discussion regarding the implementation of West Papua cultural diplomacy and defense diplomacy policy at the Ministry of Defense of the Republic of Indonesia, the following conclusions can be drawn: Researchers in analyzing used the concept of Edward III (1980). An important function for a country, among others, is the function of representative diplomacy, in which delegates from one country conduct negotiations with other countries with the aim of explaining some of these countries. Then the diplomacy function is in the negotiation function, in this function a country has the right to conduct negotiations related to its country in terms of negotiations related to trade or bilateral cooperation of a country. And finally there is a diplomatic function in the reporting function, where in this function a diplomat negotiates on cultural, military and commercial issues in his country.

4. Does in the implement the Policy for the Implementation of West Papua Cultural Diplomacy and Defense Diplomacy at the Ministry of Defense of the Republic of Indonesia, have an SOP for implement the Policy for the Implementation of West Papua Cultural Diplomacy and Defense Diplomacy at the Ministry of Defense of the Republic of Indonesia services, conduct reviews and have units that manage implement the Policy for the Implementation of West Papua Cultural Diplomacy and Defense Diplomacy at the Ministry of Defense of the Republic of Indonesia services, and evaluate the implementation of implement the Policy for the Implementation of West Papua Cultural Diplomacy and Defense Diplomacy at the Ministry of Defense of the Republic of Indonesia?

SOP implement the Policy for the Implementation of West Papua Cultural Diplomacy and Defense Diplomacy at the Ministry of Defense of the Republic of Indonesia does not currently exist and in carrying out its implementation using the 1945 Law we still use the diplomacy SOP of the Ministry of Foreign Affairs of the Republic of Indonesia as a reference in carrying out our task is to handle the implementation of the Policy for the Implementation of West Papua Cultural Diplomacy and Defense Diplomacy at the Ministry of Defense of the Republic of Indonesia. and we do the reviews every day. unit implement the Policy for the Implementation of West Papua Cultural Diplomacy and Defense Diplomacy at the Ministry 
of Defense of the Republic of Indonesia is a special diplomacy unit that handles it. and we do the reviews every day.

Bureaucratic Structure Based on the results of research and discussion regarding the implementation of West Papua cultural diplomacy and defense diplomacy policy at the Ministry of Defense of the Republic of Indonesia, the following conclusions can be drawn: Researchers in analyzing used the concept of Edward III (1980). An important function for a country, among others, is the function of representative diplomacy, in which delegates from one country conduct negotiations with other countries with the aim of explaining some of these countries. Then the diplomacy function is in the negotiation function, in this function a country has the right to conduct negotiations related to its country in terms of negotiations related to trade or bilateral cooperation of a country. And finally there is a diplomatic function in the reporting function, where in this function a diplomat negotiates on cultural, military and commercial issues in his country.

\section{A. CONCLUSION}

That policy implementation is influenced by four variables, namely:Communication, resources, disposition, and bureaucratic structure implement the Policy for the Implementation of West Papua Cultural Diplomacy and Defense Diplomacy at the Ministry of Defense of the Republic of Indonesia was successful because implement the Policy for the Implementation of West Papua Cultural Diplomacy and Defense Diplomacy at the Ministry of Defense of the Republic of Indonesia An important function for a country, among others, is the function of representative diplomacy, in which delegates from one country conduct negotiations with other countries with the aim of explaining some of these countries. Then the diplomacy function is in the negotiation function, in this function a country has the right to conduct negotiations related to its country in terms of negotiations related to trade or bilateral cooperation of a country. And finally there is a diplomatic function in the reporting function, where in this function a diplomat negotiates on cultural, military and commercial issues in his country.

Reliable communication skills are also very important in understanding what people want, focusing on the community, providing efficient service, personal approach, fostering good relations with the community. Show sympathy, speak with feelings, and provide solutions to show that you understand what society wants. Ask for community responses in the form of a service satisfaction survey so that it can be corrected if there are deficiencies in services. Limited personnel constraints such as IT and cyber forensics experts, another crucial obstacle is the limited operational budget funds, crucial problems besides legal instruments, namely the lack of human resources, budget and facilities and infrastructure to support the West Papua Cultural Implementation Policy. Diplomacy and Defense Diplomacy of the Ministry of Defense of the Republic of Indonesia. Currently the budget is only sufficient for one case per month. Weak surveillance of the use of the internet has the potential to create problems for defense diplomacy. Procedural constraints on the IT Law and from the Ministry of Communication and Information Technology (KOMINFO) are directly related to the policy on the use of information technology and internet facilities in Indonesia. It can be said that the ability of Indonesian polyclinics in cyberspace is still at the standard or beginner level. 


\section{REFERENCES}

[1] Edwards III, George C. (1980). "Implementing Public Policy". Washington DC: Congressional Quartely Press.

[2] Louise Diamond and John McDonald, "Multi-Track Diplomacy: A Systems Approach to Peace Third Edition" (Kumarian Pres 1996): 7

[3] Mefendence Jeffrey, "Track One And A Half Diplomacy And The Contemporary Of Tracks: Culture people of peace" pages, 2-3.

[4] Mark Leonard, "Public Diplomacy", (London Foreign Policy Center 2002). hhtp / fpc.org.uk / fsblob / 35.pdf (accessed December 1, 2013): 9-10

[5] Mohammad Shoelhi, "DIPLOMASI: Praktik Diplomasi Internasional"(Sembiosa RekatamaMedia, Bandung, 2011): 84

[6] Gusti Ayu. 2016. The Importance of Cultural Diplomacy and the Role of Social Media in the Cultural Diplomacy of a Country. Taken from https://id.linkedin.com/pulse/pentingnya-diplomasi-budaya-dan-peranan-social-mediadalam-arinta (accessed on 20 December 2016)

[7] Directorate of Public Diplomacy / EPMM) Triyono Wibowo in his opening speech $\geq$ Indonesia Arts and Culture as’ Soft Power Diplomacy ¥ Channel 2011 at Eldorado Hotel, Bandung.

[8] Rodon Pedrason, Asean Defense Diplomacy: The Road To Southeast Asian Defense Community, (Heidelberg: University Heidelberg, 2015) pages. 15.

[9] Gregory Winger, The Velvet Gauntlet: A Theory of Defense Diplomacy, (Vienna: IWM Junior Visiting Fellows' Conferences, 2014).

[10] I. Syawfi, Indonesian Defense Diplomacy Activities in Fulfilling Indonesia's Defense Objectives (2003-2008), (Jakarta: University of Indonesia, 2009), pp. 14.

[11] Creswell, J. W. (2013). Qualitative inquiry and research design: Choosing among five approaches (3rd ed.). Thousand Oaks, CA: Sage.

[12] https://www.kompas.com/tren/image/2019/10/28/085011465/jokowi-dan-3-janjinyasaat-berkunjung-kepegunungan-arfak-papua-barat?page $=1$ accessed on 30 January 2021 at 19.30 WIB

[13] https://www.jpnn.com/news/jokowi-kalau-tidak-salah-saya-sudah-13-kali-hadir-dipapua accessed on 30 January 2021 at 19.30 WIB 